\title{
PERTANGGUNGJAWABAN NOTARIS SEBAGAI PENERIMA TITIPAN SERTIPIKAT HAK ATAS TANAH MILIK KLIEN
}

\author{
RESPONSIBILITIES OF THE NOTARY AS A RECIPIENT OF \\ THE CLIENT'S LAND CERTIFICATE
}

\author{
Kadek Dio Anjasmara \\ Fakultas Hukum Universitas Brawijaya \\ Jalan MT Haryono Nomor 169 Malang, Kode Pos 65145 \\ E-mail : anjasmaradio@gmail.com \\ Endang Sri Kawuryan \\ Notaris/PPAT Kota Malang \\ Jalan Ciliwung Nomor 19 Kota Malang \\ E-mail : endang.kawuryan@yahoo.com
}

\begin{abstract}
In practice Notary often receive a deposit of a land certificate, where that safekeeping is generally carried out in the case of parties who will implement a binding Sales and Purchase Agreement in order to protect the interests of each party, then it is deposited to the Notary for the binding agreement of sale and purchase deed. That safekeeping activity creates legal implications considering that there are no laws and regulations that give authority to Notaries to receive such safekeeping, so that the concerned Notary must be prepared to bear the magnitude of responsibility and risks that can occur to him in the future because he has carried out positions beyond the authority granted by Constitution. This study aims to determine the responsibility of Notaries as recipients of the deposit of land certificate in terms of the relevant legislation in force. The research method used is a normative juridical research method. The results of this study indicate that a Notary who receives safekeeping of a land certificate if proven to have committed a violation that harms other parties can be held to account in a civil, criminal or administrative manner in accordance with the relevant regulations and laws.
\end{abstract}

Keywords: Notary Responsibility, Deposit Recipient, Land Title

\begin{abstract}
Abstrak
Notaris dalam praktiknya sering menerima penitipan sertipikat Hak Atas Tanah milik kliennya, dimana penitipan tersebut umumnya dilakukan dalam hal para pihak yang akan melakukan Perjanjian Pengikatan Jual Beli (PPJB) yang sifatnya belum lunas sehingga guna melindungi kepentingan masing-masing pihak, maka sertipikat tanah tersebut kemudian dititipkan kepada Notaris pembuat akta PPJB. Kegiatan penitipan tersebut menimbulkan implikasi hukum mengingat tidak ada peraturan perundang-undangan yang memberikan kewenangan kepada Notaris untuk menerima penitipan tersebut, sehingga berakibat Notaris yang bersangkutan harus siap menanggung besarnya tanggung jawab dan risiko yang dapat terjadi terhadapnya kedepan karena telah menjalankan jabatan diluar kewenangan yang diberikan oleh undang-undang. Penelitian ini bertujuan untuk menganalisis terkait bentuk pertanggungjawaban Notaris yang berkedudukan sebagai penerima titipan sertipikat hak atas tanah milik klien ditinjau dari peraturan perundang-undangan terkait yang berlaku. Metode penelitian yang digunakan adalah metode penelitian yuridis normatif. Hasil dari penelitian ini menunjukkan bahwa Notaris yang menerima penitipan sertipikat Hak Atas Tanah milik kliennya apabila terbukti telah melakukan pelanggaran yang merugikan pihak
\end{abstract}


lainnya dapat dimintai pertanggungjawabannya secara perdata, pidana atau administratif sesuai dengan peraturan perundang-undangan yang berlaku.

\section{Kata kunci: Pertanggungjawaban Notaris, Penerima Titipan, Sertipikat Hak Atas Tanah PENDAHULUAN}

Notaris merupakan pejabat umum yang kewenangannya diperoleh secara atribusi atau kewenangan yang berasal dari undang-undang, yaitu Undang-Undang Nomor 30 Tahun 2004 tentang Jabatan Notaris (selanjutnya disingkat UUJN) dan Undang-Undang Nomor 2 Tahun 2014 tentang Perubahan Atas Undang-Undang Nomor 30 Tahun 2004 tentang Jabatan Notaris (selanjutnya disingkat UUJN-P). Sehingga Notaris dalam melaksanakan atau menjalankan jabatannya harus selalu wajib berpedoman pada ketentuan yang diatur dalam Undang-Undang Jabatan Notaris maupun peraturan perundang-undangan terkait lainnya.

Namun pada praktiknya tidak jarang ditemukan Notaris yang menjalankan jabatan diluar ketentuan yang telah diatur undang-undang. Salah satunya yaitu tindakan Notaris yang bersedia menjadi penerima titipan barang berupa sertipikat Hak Atas Tanah milik kliennya. Tindakan Notaris yang berkedudukan sebagai pihak penerima titipan barang berupa sertipikat Hak Atas Tanah milik kliennya merupakan tindakan yang berada diluar kewenangan Jabatan Notaris karena tidak adanya ketentuan yang secara khusus dan tegas mengaturnya, baik dalam Undang-Undang Jabatan Notaris maupun peraturan perundang-undangan lainnya.

Penitipan sertipikat Hak Atas Tanah milik klien kepada Notaris umumnya terjadi ketika adanya transaksi Perjanjian Pengikatan Jual Beli (selanjutnya disebut PPJB). PPJB merupakan suatu bentuk perjanjian awal antara pembeli dan penjual dengan obyek hak atas tanah, dimana pembayarannya dilakukan dengan cara angsuran, dan setelah pembayarannya lunas atau setelah terpenuhinya asas tunai dan terang. ${ }^{1}$ Dalam perjanjian awal tersebut umumnya calon pembeli terlebih dahulu melakukan pembayaran awal sebagai uang muka, sehingga apabila kemudian calon pembeli membatalkan transaksi tersebut maka calon pembeli yang bersangkutan akan kehilangan uang muka yang telah dibayar sebelumnya. ${ }^{2}$

PPJB bersifat mengikat bagi para pihak untuk menunjukkan keseriusan para pihak dalam melakukan transaksi jual beli hak atas tanah dan bangunan, dimana pada saatnya nanti keseriusan tersebut akan ditandai dengan pemenuhan asas tunai dan terang berupa pelunasan secara keseluruhan terhadap pembelian hak atas tanah dan kemudian dilakukannya penandatanganan Akta Jual Beli (AJB) dihadapan Pejabat Pembuat Akta Tanah (PPAT), agar selanjutnya diteruskan dengan melakukan pendaftaran atas peralihan hak atas tanah ke Kantor Pertanahan Kota/Kabupaten setempat, untuk kemudian dicatatkan (balik nama) kepemilikan baru hak atas tanah ke dalam buku tanah yang tersimpan di Badan Pertanahan Nasional (BPN). ${ }^{3}$ Adapun kewenangan pembuatan akta PPJB berada ditangan Notaris.

Mengingat pembayaran dalam transaksi PPJB dilakukan secara angsuran atau bertahap dalam jangka waktu pelunasan yang tidak sebentar, maka guna melindungi kepentingan masing-masing pihak umumnya terlebih dahulu para pihak sepakat untuk melakukan penitipan sertipikat hak atas tanah (obyek PPJB) kepada Notaris hingga AJB selesai dibuat. Bukti telah dititipkannya sertipikat hak atas tanah milik klien kepada Notaris umumnya dilakukan dengan hanya membuat suatu surat tanda terima oleh Notaris untuk diberikan kepada kliennya selaku pemilik sertipikat hak atas tanah tersebut. Selain itu ada juga Notaris yang mencantumkan

\footnotetext{
${ }^{1}$ Herlien Budiono, Demikian Akta Ini : Tanya Jawab Mengenai Pembuatan Akta Notaris di dalam Praktik, PT. Citra Aditya Bakti, Bandung, 2018, hlm. 115.

${ }_{2}^{2}$ Putri, Dewi Kunia dan Purnawan, Amin, Perbedaan Perjanjian Pengikatan Jual Beli Lunas dengan Perjanjian Pengikatan Jual Beli Tidak Lunas, Jurnal Akta, Vol. 04, No. 04, 2017, http://jurnal.unissula.ac.id/index.php/akta/articlel download/2505/1868, diakses tanggal 2 April 2019.

${ }^{3}$ Supriyadi, Kedudukan Perjanjian Pengikatan Jual Beli Hak Atas Tanah Dalam Perspektif Hukum Pertanahan, Arena Hukum, Vol. 10. No. 02, 2017, https://doi.org/10.21776/ub.arenahukum.2017.01002.3, diakses tanggal 2 April 2019.
} 
klausula tentang kesepakatan para pihak untuk menitipkan sertipikat hak atas tanah kepadanya tersebut kedalam akta yang dibuat dihadapan Notaris yang bersangkutan.

Penitipan barang merupakan perbuatan hukum yang didasarkan adanya perjanjian terlebih dahulu. Jadi penitipan barang merupakan salah satu jenis dari perjanjian. Di dalam hukum perjanjian, penitipan barang termasuk kedalam jenis perjanjian nominaat, yaitu perjanjian bernama yang ketentuannya secara khusus diatur pada Buku III Kitab Undang-Undang Hukum Perdata (selanjutnya disingkat KUHPerdata) Pasal 1694 sampai dengan Pasal 1739 KUHPerdata tentang Penitipan Barang. Didalam ketentuan tersebut tidak disebutkan secara jelas terkait dengan pengertian dari penitipan barang, namun dalam Pasal 1694 KUHPerdata dijelaskan mengenai keadaan terjadinya penitipan barang, yaitu penitipan barang telah terjadi ketika seseorang menerima suatu barang dari orang lainnya, dengan disertai syarat agar orang yang menerima barang tersebut menyimpannya dan mengembalikannya lagi dalam wujud asalnya kepada pemberi barang.

Kesediaan Notaris untuk menerima penitipan sertipikat Hak Atas Tanah milik klien umumnya didasari atas itikad baik Notaris guna menjaga kepentingan masing-masing pihak karena mengingat dalam PPJB pelunasannya dilakukan secara angsuran atau bertahap dalam jangka waktu berbulan-bulan bahkan tak jarang hingga bertahun-tahun ${ }^{4}$, sehingga jika sertipikat Hak Atas Tanah tersebut di pegang oleh salah satu pihak dan jika pihak tersebut tidak memiliki itikad baik, maka akan berpotensi menimbulkan masalah terkait penyalahgunaan terhadap sertipikat Hak Atas Tanah tersebut. Tindakan Notaris untuk menjaga kepentingan para pihak dalam suatu perbuatan hukum sejatinya telah sesuai dengan Pasal 16 ayat (1) huruf a UUJN-P. Kendati demikian penafsiran makna terhadap frasa "menjaga kepentingan para pihak" dalam ketentuan tersebut tidak disebutkan secara jelas sehingga sifatnya masih sangat umum dan multitafsir, dan oleh karena itu ketentuan tersebut tidak dapat dijadikan sebagai dasar hukum yang kuat bagi Notaris untuk melakukan suatu tindakan atau terobosan baru dalam menjalankan jabatannya diluar yang telah ditentukan UUJN dan UUJN-P, yang dalam hal ini yaitu tindakan Notaris untuk menjadi penerima titipan sertipikat Hak Atas Tanah Milik Kliennya.

Selain itu, dengan menjadi pihak penerima titipan barang berupa sertipikat Hak Atas Tanah milik kliennya, maka Notaris yang bersangkutan harus menjalankan kewajiban dan tanggungjawabnya sebagai pihak penerima titipan barang dengan tunduk pada ketentuan yang mengatur mengenai penitipan barang, yaitu Pasal 1694 sampai dengan Pasal 1739 KUHPerdata. Khususnya Pasal 1706, Pasal 1707 dan Pasal 1708 KUHPerdata yang mengharuskan seorang penerima titipan barang untuk sepenuhnya menjaga dan memastikan keutuhan barang yang dititipkan kepadanya.

Sehingga berdasarkan hal tersebut, mengingat hingga saat ini masih belum adanya aturan yang memberi kewenangan Notaris untuk menerima atau menolak penitipan Sertipikat Hak Atas Tanah milik kliennya, serta tidak ada aturan yang mengatur secara khusus mengenai bentuk pertanggungjawaban Notaris yang menjadi penerima titipan sertipikat Hak Atas Tanah milik kliennya, baik itu dalam Undang-Undang Jabatan Notaris maupun peraturan perundangundangan lainnya, maka dengan adanya penitipan sertipikat Hak Atas Tanah dari klien kepada Notaris kemudian menimbulkan suatu implikasi hukum mengingat besarnya resiko dan tanggung jawab yang dapat dihadapi kedepan, baik bagi pihak klien selaku pemilik sertipikat hak atas tanah, maupun bagi Notaris sendiri selaku pihak yang berkedudukan sebagai penerima titipan barang berupa sertipikat hak atas tanah tersebut.

${ }^{4}$ Puspo Dewi Retno, Pranoto dan Purwadi Hari, Pembatalan Akta Perjanjian Pengikatan Jual Beli Akibat Wanprestasi (Studi Kasus Putusan Nomor: 200/Pdt.G/2012/PN.Jkt.Sel), Jurnal Repertorium, Vol. 04, No. 07, 2017, https://jurnal.uns. ac.id/repertorium/article/download/18296/14498, diakses tanggal 2 April 2019. 
Berkaitan dengan hal tersebut, terdapat kekosongan hukum dalam kaitannya dengan kedudukan dan tanggung jawab seorang Notaris sebagai penerima titipan barang berupa Sertipikat Hak Atas Tanah milik kliennya, dimana belum ada peraturan perundang-undangan yang secara khusus dan tegas mengaturnya, sehingga menimbulkan ketidakjelasan terkait kepastian hukum mengenai legalitas kewenangan dan bentuk pertanggungjawaban Notaris yang berkedudukan sebagai penerima titipan Sertipikat Hak Atas Tanah milik kliennya.

Dalam pembuatan penelitian ini, setelah dilakukan penelusuran terhadap penelitianpenelitian terdahulu, penulis menemukan penelitian ilmiah yang memiliki topik bahasan yang cukup dekat dengan topik bahasan jurnal ini, yaitu diantaranya penelitian yang dilakukan oleh Desy Rositawati pada tahun 2017 dengan judul "Penyimpanan Protokol Notaris Secara Elektronik Dalam Kaitan Cyber Notary". Adapun bentuk kebaruan penelitian ini terhadap penelitian terdahulu tersebut dapat dilihat pada penelitian ini yang menggunakan teori pertanggungjawaban hukum sebagai pisau analisis penulis dalam menganalisis isu hukum terkait bentuk pertanggungjawaban Notaris dalam penitipan sertipikat hak atas tanah milik klien. Selain itu, penelitian ini juga menyertakan wawancara terhadap seorang Notaris yang pernah mengalami kehilangan sertipikat hak atas tanah milik klien yang dititipkan kepadanya, sehingga dari hal tersebut penelitian ini dapat memperoleh hasil penelitian yang sifatnya baru dan dapat dipertanggungjawabkan.

Penelitian ini menggunakan metode penelitian yuridis normatif, dimana fokus kajiannya berangkat dari adanya kekosongan norma terkait dengan bentuk pertanggungjawaban Notaris yang berkedudukan sebagai penerima titipan sertipikat Hak Atas Tanah milik klien. Penulis menggunakan jenis metode penelitian yuridis normatif, dengan tujuan untuk melakukan inventarisasi terhadap peraturan perundang-undangan dan teori-teori serta doktrin-doktrin hukum yang berkaitan dengan isu hukum pada penelitian ini. Metode pendekatan yang digunakan yaitu metode pendekatan peraturan perundang-undangan (statute approach) dan metode pendekatan konseptual (conceptual approach). Sumber bahan hukum penelitian ini menggunakan bahan hukum primer dan bahan hukum sekunder. Bahan hukum primer terdiri dari peraturan perundang-undangan terkait yang berlaku seperti Kitab Undang-Undang Hukum Perdata (KUHPerdata), Undang-Undang Nomor 30 Tahun 2004 tentang Jabatan Notaris (UUJN), Undang-Undang Nomor 2 Tahun 2014 tentang perubahan atas Undang-Undang Nomor 30 Tahun 2004 tentang Jabatan Notaris (UUJN-P), Undang-Undang Nomor 5 Tahun 1960 tentang Peraturan Dasar Pokok-Pokok Agraria (UUPA), dan Peraturan Pemerintah Nomor 24 Tahun 1997 tentang Pendaftaran Tanah (PP Pendaftaran Tanah). Bahan hukum sekunder terdiri dari literatur-literatur hukum sebagaimana yang disebutkan pada bagian daftar pustaka penelitian ini, dan wawancara dengan seorang Notaris yang bertempat kedudukan di Kabupaten Badung Provinsi Bali. Teknik pengumpulan bahan hukum yang digunakan pada penelitian ini yaitu berupa studi dokumen terhadap bahan hukum primer dan sekunder. Sementara teknik analisis yang digunakan yaitu dengan teknik analisis deskriptif dan dilanjutkan dengan teknik analisis evaluatif.

Berdasarkan uraian tersebut diatas, maka permasalahan yang akan dikaji dalam penelitian ini yaitu : Bagaimana pertanggungjawaban Notaris dalam menjalankan jabatannya? dan Bagaimana bentuk pertanggungjawaban Notaris sebagai penerima titipan sertipikat Hak Atas Tanah milik klien?. Penelitian ini bertujuan untuk memahami dan menganalisis terkait dengan bentuk pertanggungjawaban Notaris yang berkedudukan sebagai penerima titipan sertipikat hak atas tanah milik klien ditinjau dari peraturan perundang-undangan terkait yang berlaku.

\section{PEMBAHASAN}

\section{Pertanggungjawaban Notaris Dalam Menjalankan Jabatan}


Pertanggungjawaban adalah keadaan wajib untuk menanggung segala sesuatu selama terdapat sesuatu hal yang dapat dituntut, dipersalahkan dan sebagainya. ${ }^{5}$ Pada umumnya seseorang baru dapat dikatakan mampu untuk bertanggungjawab apabila orang tersebut : 1). Dalam keadaan sadar atau jiwanya tidak sedang terkena penyakit kronis atau sementara, tidak cacat dalam pertumbuhan, serta tidak dalam keadaan terkejut atau sedang dihipnotis; 2). Sadar terhadap perbuatan yang dilakukannya dan dapat mengetahui dampak atas tindakannya tersebut sehingga ia sadar dan tahu akan akibat yang timbul dari perbuatan yang telah dilakukannya. ${ }^{6}$

Setiap pertanggungjawaban harus memiliki dasar yang jelas, yaitu harus adanya suatu hal yang kemudian menimbulkan hak hukum bagi seseorang untuk menuntut kepada orang lain sekaligus untuk dapat melahirkan suatu kewajiban hukum bagi orang lain untuk memberikan pertanggungjawabannya. ${ }^{7}$ Adapun hal yang menjadi dasar untuk menuntut pertanggungjawaban yaitu adanya perbuatan salah dari orang lain, sehingga pertanggungjawaban baru akan terjadi ketika didahului atas adanya suatu perbuatan.

Dalam kamus hukum terdapat dua istilah yang menunjukkan pada suatu pertanggungjawaban, yaitu diantaranya istilah responsibility dan liability. Responsibility diartikan sebagai hal yang dapat dipertanggungjawabkan terhadap suatu kewajiban, yang juga meliputi putusan, keterampilan, kemampuan, kecakapan, serta kewajiban untuk bertanggungjawab terhadap undang-undang yang dilaksanakan. Sementara istilah liability diartikan sebagai istilah hukum yang lebih luas yang menunjuk hampir seluruh risiko atau tanggung jawab, yang sifatnya pasti, yang dapat meliputi seluruh hak dan kewajiban, baik yang telah ada atau yang berpotensi akan ada seperti kerugian, ancaman, kejahatan, biaya atau kondisi yang menimbulkan tugas untuk melaksanakan undang-undang. Dari pengertian tersebut, penggunaan istilah liability dianggap lebih tepat jika dikaitkan dengan pertanggungjawaban hukum, karena liability mengandung prinsip tanggung jawab/gugat akibat kesalahan yang dilakukan oleh seseorang. ${ }^{8}$

Purnadi Purbacaraka dalam bukunya berpendapat bahwa sumber dari suatu tanggung jawab hukum yaitu dari adanya penggunaan fasilitas dalam penerapan kemampuan tiap orang untuk menggunakan hak atau melaksanakan kewajibannya. Setiap pelaksanaan kewajiban dan setiap penggunaan hak, baik yang dilaksanakan secara penuh atau tidak, pada dasarnya tetap harus disertai dengan adanya suatu tanggung jawab, ${ }^{9}$ begitu juga dengan pelaksanaan kewenangan suatu jabatan seperti Notaris.

Dalam menjalankan jabatannya, seorang Notaris harus mempunyai tanggung jawab moral terhadap jabatannya tersebut. Paul F. Camanisch berpendapat bahwa jabatan adalah suatu masyarakat moral yang memiliki cita-cita dan nilai-nilai luhur bersama. Setiap jabatan mempunyai kewenangan sendiri dan tanggung jawab yang khusus. Suatu jabatan memiliki acuan atau pedoman dalam menjalankan jabatannya yang disebut sebagai Kode Etik Jabatan. ${ }^{10}$ Begitupula dengan jabatan Notaris yang memiliki Kode Etik Notaris sebagai pedoman dalam menjalankan jabatannya agar sesuai dengan peraturan perundang-undangan terkait yang berlaku. Setiap jabatan, termasuk jabatan Notaris

${ }^{5}$ Tim Penyusun Kamus Pusat Pembinaan dan Pengembangan Bahasa. Kamus Besar Bahasa Indonesia, Balai Pustaka, Jakarta, 1989, hlm. 923.

${ }^{6}$ Edi Yunara, Korupsi dan Pertanggungjawaban Pidana Korporasi, Citra Aditya Bakti, Bandung, 2012, hlm. 54.

${ }^{7}$ Titik Triwulan dan Shinta Febrian, Perlindungan Hukum Bagi Pasien, Prestasi Pustaka, Jakarta, 2010, hlm. 48.

${ }^{8}$ Ridwan H.R., Hukum Adminstrasi Negara, Raja Grafindo Persada, Jakarta, 2006, hlm. 336.

${ }^{9}$ Purnadi Purbacaraka, Perihal Kaedah Hukum, Citra Aditya, Bandung, 2010, hlm. 37.

${ }^{10}$ E. Sumaryono, Etika Profesi Hukum : Norma-Norma Bagi Penegak Hukum, Kanisius, Yogyakarta, 1995, hlm. 147.

210 IUS Kajian Hukum dan Keadilan 
membutuhkan adanya tanggungjawab yang besar baik secara individual maupun sosial agar selalu taat terhadap hukum positif serta bersedia tunduk pada Kode Etik Notaris. ${ }^{11}$

Teori pertanggungjawaban hukum secara umum menyatakan bahwa setiap orang yang melakukan perbuatan melanggar hukum, tidak dikecualikan kepada pemerintah maupun suatu jabatan, harus mempertanggungjawabkan setiap tindakannya tersebut, baik karena adanya kesengajaan, kelalaian atau tanpa kesalahan. Dari adanya pertanggungjawaban tersebut kemudian akan melahirkan beberapa bentuk pertanggungjawaban hukum diantaranya berupa tanggung jawab perdata, tanggung jawab administratif, dan tanggung jawab pidana. ${ }^{12}$

Pada jabatan Notaris, sebagai pejabat umum yang dalam menjalankan jabatannya tidak terlepas dari kemungkinan melakukan suatu kesalahan atau perbuatan melanggar hukum, juga dapat dimintai pertanggungjawabannya. Berdasarkan Undang-Undang Jabatan Notaris dan Kode Etik Notaris, ditentukan bahwa apabila terdapat Notaris yang dalam menjalankan jabatannya terbukti melakukan pelanggaran, maka Notaris yang bersangkutan wajib untuk bertanggungjawab atas tindakannya tersebut dengan cara dijatuhi sanksi, baik itu berupa sanksi perdata, sanksi administratif, maupun sanksi pidana. Jadi bentuk pertanggungjawaan dari jabatan Notaris yaitu berupa pengenaan sanksi. ${ }^{13}$

Dalam UUJN, sanksi-sanksi yang dapat dikenakan atau dibebankan kepada Notaris yang melakukan pelanggaran diatur dan dikumpulkan dalam BAB XI Pasal 84 dan Pasal 85 tentang Ketentuan Sanksi. Sementara dalam UUJN-P, BAB XI dari UUJN yang membahas ketentuan mengenai sanksi telah dihapuskan, dimana sanksi-sanksi tersebut tidak dikumpulkan dalam satu bab lagi, melainkan langsung disertakan pada setiap pasal yang berkaitan dengan pengenaan sanksinya. Sehingga jika ada pelanggaran terhadap pasal yang tidak disertai sanksi, maka tidak ada sanksi yang dapat dikenakan terhadap Notaris tersebut. ${ }^{14}$

Sanksi sebagai suatu paksaan berdasarkan hukum yang ditujukan kepada Notaris merupakan sebagai bentuk penyadaran terhadap Notaris yang bersangkutan karena dalam menjalankan jabatannya telah melakukan pelanggaran terhadap ketentuanketentuan mengenai pelaksanaan tugas jabatan Notaris sebagaimana yang telah ditentukan dalam Undang-Undang Jabatan Notaris, sehingga Notaris yang bersangkutan dapat kembali menjalankan jabatannya dengan tertib sesuai dengan Undang-Undang Jabatan Notaris. ${ }^{15}$ Sementara bagi masyarakat, pemberian sanksi terhadap Notaris dapat memberikan perlindungan kepada masyarakat yang berkepentingan dari adanya tindakan Notaris yang merugikan, salah satunya seperti pembuatan akta yang tidak melindungi hak-hak masyarakat yang bersangkutan. Pengenaan sanksi terhadap Notaris tersebut sejatinya dilakukan untuk menjaga martabat lembaga Notaris sebagai lembaga terhormat yang dipercayai masyarakat, karena jika Notaris melakukan pelanggaran maka dapat menurunkan tingkat kepercayaan masyarakat terhadap jabatan Notaris. ${ }^{16}$

\footnotetext{
${ }^{11}$ Liliana Tedjosaputro, Mal Praktek Notaris Dalam Hukum Pidana, CV. Agung, Semarang, 1991.hlm. 4.

${ }^{12}$ Munir Fuady, Perbuatan Melawan Hukum, PT Citra Aditya Bakti, Bandung, 2010, hlm. 147.

${ }^{13}$ Habib Adjie, Sanksi Perdata dan Administratif Terhadap Notaris Sebagai Pejabat Publik, Refika Aditama, Bandung, 2009, (selanjutnya disingkat Habib Adjie I), hlm. 120.

${ }^{14}$ Habib Adjie, Penafsiran Tematik Hukum Notaris Indonesia : Berdasarkan Undang-Undang Nomor 2 Tahun 2014 tentang Perubahan Atas Undang-Undang Nomor 30 Tahun 2004 tentang Jabatan Notaris, PT. Refika Aditama, Bandung, 2015, (selanjutnya disingkat Habib Adjie II), hlm. 57.

${ }_{15}$ Sjaifurrachman dan Habib Adjie, Aspek Pertanggungjawaban Notaris dalam Pembuatan Akta, CV. Mandar Maju, Bandung, 2011, hlm. 194.

${ }^{16}$ Ibid.
} 
Notaris sebagai pejabat umum yang mempunyai kewenangan utama yaitu untuk membuat akta autentik mengenai semua perbuatan, perjanjian dan penetapan yang diharuskan oleh peraturan perundang-undangan dan/atau dikehendaki oleh pihak yang berkepentingan, maka Notaris wajib bertanggungjawab terhadap akta yang dibuatnya tersebut dan Notaris juga harus dapat mempertanggungjawabkan segala tindakannya dalam menjalankan jabatan Notaris, baik itu pertanggungjawaban secara Perdata, pertanggungjawaban secara Administratif, ataupun pertanggungjawaban secara Pidana, dengan penjelasannya sebagai berikut.

1. Pertanggungjawaban Perdata Notaris

Dalam KUHPerdata ditentukan bahwa pertanggungjawaban secara perdata merupakan tanggung jawab yang diberikan dengan pengenaan sanksi keperdataan yang terjadi karena adanya tindakan wanprestasi terhadap perjanjian-perjanjian atau perbuatan melanggar hukum (onrechtmatige daad) terhadap undang-undang. Adapun sanksi keperdataan tersebut yaitu diantaranya dapat berupa penggantian biaya, ganti rugi, dan bunga. ${ }^{17}$

Sementara mengenai sebab terjadinya pertanggungjawaban perdata tersebut dapat terjadi karena 3 (tiga) hal yaitu: 1). Tanggung jawab karena unsur kesalahan karena kesengajaan (Pasal 1365 KUHPerdata); 2). Tanggung Jawab karena unsur kesalahan karena kelalaian (Pasal 1366 KUHPerdata); 3). TanggungJawab Mutlak dengan tanpa kesalahan (Pasal 1367 KUHPerdata). ${ }^{18}$

Dalam Undang-UndangJabatan Notaris, ditentukan bahwa Notaris dapat dimintai pertanggungjawabannyasecara perdata apabilaterdapatpihakyangmenderitakerugian akibat adanya tindakan pelanggaran yang dilakukan oleh Notaris terhadap ketentuanketentuan mengenai pembuatan akta yang mengakibatkan suatu akta hanya memiliki kekuatan pembuktian sebagai akta di bawah tangan atau suatu akta menjadi batal demi hukum. Pihak yang menderita kerugian akibat hal tersebut dapat meminta pertanggungjawaban perdata kepada Notaris yang bersangkutan dengan menuntut penggantian biaya, ganti rugi, dan bunga.

Adapun ketentuan-ketentuan yang mengatur terkait dengan pengenaan pertanggungjawaban perdata kepada Notaris dalam Undang-Undang Jabatan Notaris yaitu :

1).Apabila Kedudukan akta Notaris menjadi akta yang mempunyai kekuatan pembuktian sebagai akta dibawah tangan tanpa disertai sanksi dapat menjadi alasan bagi pihak yang menderita kerugian untuk menuntut penggantian biaya, ganti rugi, dan bunga kepada Notaris, yaitu diantaranya : Pasal 16 ayat (9) UUJN-P terkait pelanggaran ketentuan pembacaan akta; Pasal 41 UUJN-P terkait pelanggaran Pasal 38, 39, 40 UUJN-P tentang bentuk akta, syarat penghadap dan saksi.

2).Apabila kedudukan akta Notaris menjadi akta yang hanya mempunyai kekuatan pembuktian sebagai akta di bawah tangan yang disertai sanksi berupa dapat menjadi alasan bagi pihak yang menderita kerugian untuk menuntut penggantian biaya, ganti rugi, dan bunga kepada Notaris, yaitu diantaranya : Pasal 44 ayat (4) UUJN-P terkait pelanggaran ketentuan penandatanganan akta setelah akta dibacakan; Pasal 48 ayat (3) UUJN-P, Pasal 49 ayat (4) UUJN-P, Pasal 50 ayat (5) UUJN-P, dan Pasal 51 ayat (4) UUJN-P terkait pelanggaran ketentuan perubahan dan pembetulan akta; Pasal 52 ayat (3) UUJN tentang pelanggaran ketentuan Pasal 52 ayat (1) UUJN

${ }^{17}$ Ibid, hlm. 195 .

${ }^{18}$ M. Luthfan Hadi Darus, Hukum Notariat dan Tanggung Jawab Jabatan Notaris, UII Press, Yogyakarta, 2017, hlm. 64 . 
tentang pembuatan akta untuk Notaris sendiri, isteri/suami atau orang lain yang mempunyai hubungan kekeluargaan dengan Notaris.

3).Apabila melanggar ketentuan Pasal 16 ayat (1) huruf $\mathrm{j}$ tentang kewajiban Notaris untuk mengirimkan daftar akta wasiat kepada kementerian yang menyelenggarakan urusan pemerintahan di bidang hukum, yang disertai sanksi perdata berupa dapat menjadi alasan bagi pihak yang menderita kerugian untuk menuntut penggantian biaya, ganti rugi, dan bunga kepada Notaris, yaitu pada Pasal 16 ayat (12) UUJN-P.

Jika terhadap kedudukan akta yang mempunyai kekuatan nilai pembuktian sebagai akta di bawah tangan dan tanpa disertakan ketentuan sanksi berupa dapat menjadi alasan bagi pihak yang menderita kerugian untuk kemudian menuntut kepada Notaris untuk melakukan penggantian biaya, ganti rugi, dan bunga sebagaimana tersebut diatas yang terdapat dalam Pasal 16 ayat (9) dan Pasal 41 UUJN-P, maka secara normatif penghadap yang mengalami kerugian tidak dapat menuntut/menggungat Notaris yang bersangkutan. Kendati demikian, karena menggungat/menuntutadalahhaksetiaporang,makameskipunterhadapkedudukan akta yang mempunyai kekuatan pembuktian sebagai akta dibawah tangan dan tanpa sanksi berupa dapat dijadikan alasan oleh pihak yang mengalami kerugian untuk kemudian menuntut penggantian biaya, ganti rugi, dan bunga kepada Notaris, maka bagi para pihak/penghadap yang merasa dirugikan tetap saja dapat mengajukan gugatan atau tuntutan kepada Notaris yang bersangkutan ke Pengadilan Umum dengan dasar gugatan ganti rugi dalam ketentuan KUHPerdata. ${ }^{19}$

2. Pertanggungjawaban Administratif Notaris

Pertanggungjawaban administratif pada umumnya baru terjadi ketika terdapat seseorang atau lembaga yang telah melakukan pelanggaran administratif. Pelanggaran administratif merupakan pelanggaran yang berkaitan dengan administratif. Administratif adalah usaha atau kegiatan yang berkaitan dengan penyelenggaraan perkantoran atau tata usaha. ${ }^{20}$ Mengingat pertanggungjawaban administratif terjadi karena adanya pelanggaran, maka kemudian pertanggungjawaban administratif diistilahkan juga sanksi administratif. Sanksi administratif dapat dijatuhkan kepada setiap orang maupun kepada suatu jabatan termasuk Notaris.

Berdasarkan Pasal 1 angka 1 Peraturan Menteri Hukum dan Hak Asasi Manusia Nomor 61 Tahun 2016 tentang Tata Cara Penjatuhan Sanksi administratif terhadap Notaris, ditentukan pengertian dari Sanksi administratif yaitu sanksi atau hukuman yang dijatuhkan oleh pejabat yang berwenang kepada Notaris karena melakukan pelanggaran yang diwajibkan atau memenuhi ketentuan yang dilarang oleh peraturan perundang-undangan yang berlaku, khususnya Undang-Undang Jabatan Notaris. Tujuan pengenaan sanksi administratif yaitu untuk memberikan efek jera terhadap Notaris yang dalam menjalankan jabatannya telah melakukan pelanggaran terhadap Kode Etik Notaris, Undang-Undang Jabatan Notaris maupun peraturan perundangundangan lainnya, sehingga melalui pengenaan sanksi administratif terhadap Notaris tersebutkemudiandapatmenjagakualitaspelayananhukumNotariskepadamasyarakat, sertamenjagamartabatlembaga Notarissebagailembagaterhormatyangtelahdipercayai masyarakat.

Adapun bentuk dari pertanggungjawaban atau sanksi administratif yang dapat dikenakan kepada Notaris berdasarkan Undang-Undang Jabatan Notaris yaitu diantaranyaterdiridari:1).PeringatanLisan;2).Peringatan Tertulis;3).Pemberhentian

\footnotetext{
${ }^{19}$ Habib Adjie II, Op. Cit., hlm. 61.

${ }^{20}$ Salim H.S., Peraturan Jabatan Notaris, Sinar Grafika, Jakarta, 2018, hlm. 205.
} 
Sementara; 4). Pemberhentian dengan Hormat; 5). Pemberhentian dengan Tidak Hormat.

Sementara ketentuan-ketentuan yang mengatur terkait dengan penjatuhan sanksi administratif tersebut yaitu :

1).Pengenaan Sanksi Administratif berupa Peringatan Tertulis, yaitu terdapat pada ketentuan Pasal 16 ayat (13) UUJN-P terkaitpelanggaranterhadapkewajiban Notaris dalam menerima calon Notaris magang;

2).Pengenaan Sanksi Administratif berupa Pemberhentian Sementara, yaitu terdapat pada ketentuan Pasal 9 ayat (1) UUJN-P;

3).Pengenaan Sanksi Administratif berupa Pemberhentian dengan Hormat, yaitu terdapat pada ketentuan Pasal 8 ayat (1) UUJN;

4). Pengenaan Sanksi Administratif berupa Pemberhentian dengan Tidak Hormat, yaitu terdapat pada ketentuan Pasal 12 UUJN dan Pasal 13 UUJN;

5).Pengenaan Sanksi Administratif berupa Peringatan Tertulis, Pemberhentuan Sementara, Pemberhentian dengan Hormat, dan Pemberhentian dengan Tidak Hormat, yaitu diantaranya terdapat pada ketentuan: Pasal 7 ayat (2) UUJN-P terkait pelanggaran terhadap hal yang harus dilakukan setelah pengambilan sumpah/janji jabatan Notaris; Pasal 16 ayat (11) UUJN-P terkait pelanggaran terhadap kewajiban Notaris pada Pasal 16 ayat (1) UUJN-P; Pasal 17 ayat (2) UUJN-P terkait pelanggaran terhadap larangan Notaris; Pasal 19 ayat (4) UUJN-P terkait pelanggaran terhadap tempat kedudukan Notaris sebagai PPAT yang wajib mengikuti tempat kedudukan Notaris; Pasal 32 ayat (4) UUJN-P terkait pelanggaran terhadap pelaksanaan cuti; Pasal 54 ayat (2) UUJN-P terkait pelanggaran untuk merahasiakan segala sesuatu mengenai akta yang dibuat Notaris; Pasal 65 A UUJN-P terkait pelanggaran terhadap Pasal 58 dan Pasal 59 UUJN tentang pembuatan daftar akta dan pembuatan daftar surat lain yang dibuat oleh Notaris, yang disertai pembuatan daftar klappernya.

6).Pengenaan Sanksi Administratif berupa Peringatan Lisan, Peringatan Tertulis, Pemberhentuan Sementara, Pemberhentian dengan Hormat, dan Pemberhentian dengan Tidak Hormat, yaitu terdapat pada ketentuan Pasal 37 ayat (2) UUJN-P terkait pelanggaran terhadap kewajiban Notaris memberikan jasa hukum di bidang kenotariatan secara cuma-cuma kepada orang yang tidak mampu.

Pertanggungjawaban Notaris secara Administratif dapat dimintakan melalui lembaga/organisasi Notaris atau pejabat yang berwenang untuk menjatuhkan sanksi administratif kepada Notaris yaitu diantaranya : Majelis Pengawas Wilayah Notaris; Majelis Pengawas Pusat Notaris; dan Menteri Hukum dan Hak Asasi Manusia. Pengenaan pertanggungjawaban administratif kepada Notaris berbeda dengan pengenaan pertanggungjawaban perdata dan pidana yang umumnya harus melalui proses Pengadilan. Kendati demikian, Pengadilan atau Hakim melalui amar putusannya dapat meneruskan kepada pejabat yang berwenang tersebut untuk menindaklanjutiputusannyagunamenjatuhkansanksiadministratifkepadaNotaris yang terbukti melakukan pelanggaran.

3. Pertanggungjawaban Pidana Notaris

Pelanggaran terhadap Undang-Undang Jabatan Notaris akan berakibat timbulnya pertanggungjawaban dari pengemban jabatan Notaris, baik itu berupa pertanggungjawabanperdata danpertanggungjawabanadministratifsebagaimanayang telah dijelaskan sebelumnya. Selain dua jenis pertanggungjawaban tersebut, dalam praktikditemukanfaktabahwaNotarisyangmelakukanpelanggaranterhadapperaturan 
jabatannya juga dapat dikualifikasikan sebagai suatu tindak pidana, sehingga tidak jarang Notaris juga dapat dimintai pertanggungjawabannya secara pidana.

Pasal 15 ayat (1) UUJN-P menentukan bahwa "kewenangan utama Notaris yaitu untuk membuat akta autentik mengenai perbuatan, perjanjian, dan penetapan yang diharuskan oleh peraturan perundang-undangan dan/atau yang dikehendaki oleh pihak yang berkepentingan". Notaris diberikan tugas jabatan untuk membuat akta autentik sebagai alat bukti berdasarkan permintaan yang dikehendaki para pihak mengenai suatu perbuatan hukum tertentu dalam lingkup hukum perdata. Pembuatan akta autentik oleh Notaris didasarkan pada keterangan atau pernyataan para pihak yang dinyatakan, diterangkan atau diperlihatkan kepada Notaris, dimana Notaris selanjutnya mengkonstatir secara lahiriah, secara formal, dan secara materiil dengan tetapberpedoman padaprosedurpembuatan akta serta peraturan perundang-undangan terkait lainnya yang mengatur tentang perbuatan hukum yang akan dituangkan dalam akta. $^{21}$

BerdasarkankewenanganNotaristersebutdalampraktiknyatidakjarangditemukan ada akta Notaris yang dipermasalahkan oleh para pihak atau pihak lainnya, yang kemudian tak jarang Notaris juga dianggap turut serta melakukan atau membantu melakukan suatu tindak pidana, seperti membuat atau memberikan keterangan palsu ke dalam akta autentuk yang dibuatnya. Selain itu terdapat juga hal lainnya terkait kewenangan Notaris dalam menjalankan jabatannya yang berujung pada tuntutan pidana dari para pihak atau pihak lain yang terkait.

Pertanggungjawaban pidana tidak terlepas dari sanksi yang akan dijatuhkan sebagai akibat dari suatu pelanggaran. Dalam Undang-Undang Jabatan Notaris tidak diatur secara khusus terkait pertanggungjawaban pidana atau sanksi pidana terhadap Notaris. Kendati demikian, apabila terdapat Notaris yang telah terbukti di Pengadilan melakukan pelanggaran pidana, maka Notaris tersebut dapat dikenakan sanksi pidana berdasarkan Kitab Undang-Undang Hukum Pidana (KUHP). ${ }^{22}$ Hal tersebut merujuk pada ketentuan Pasal 63 ayat (2) KUHP yang pada intinya menentukan bahwa "jika suatu perbuatan masuk dalam suatu aturan pidana yang umum dan juga diatur dalam pidana yang khusus maka aturan pidana yang khusus-lah yang berlaku, begitu juga sebaliknyaapabilaketentuanpidanakhusustidakmengatur, makaterhadappelanggaran tersebut akan dikenakan ketentuan pidana umum yaitu KUHP".

Secara umum, terdapat beberapa tindak pidana yang sering dituduhkan kepada Notaris oleh para pihak dan/atau seringjuga dilakukan oleh Notaris dalam menjalankan jabatannya, diantaranya pasal yang berkaitan dengan tindakan kesengajaan, yaitu sebagai berikut : ${ }^{23}$

1).Tindak Pidana tentang Pelanggaran Jabatan, sebagaimana yang ditentukan dalam Pasal 52 KUHP;

2). Tindak Pidana tentang Percobaan, sebagaimana yang ditentukan dalam Pasal 53 KUHP;

3).Tindak Pidana tentang Penyertaan, sebagaimana yang ditentukan dalam Pasal 55 KUHP;

4). TindakPidanatentangPemalsuanSurat, sebagaimanadiantaranyayangditentukan dalam Pasal 263, Pasal 264, dan Pasal 266 KUHP;

\footnotetext{
${ }^{21}$ Sjaifurrachman dan Habib Adjie, Op. Cit., hlm. 207.

${ }^{22}$ Luthfan Hadi Darus, Op. Cit., hlm. 81.

${ }^{23}$ Sulhan, Irwansyah Lubis, dan Anhar Syahnel, Buku 1 : Profesi Notaris dan Pejabat Pembuat Akta Tanah (Pandua Praktis Dan Murah Taat Hukum), Mitra Wacana Media, Bogor, 2018, hlm. 22.
} 
5).Tindak Pidana tentang Penggelapan, sebagaimana yang ditentukan dalam Pasal 372 KUHP;

6).Tindak Pidana tentang Penipuan, sebagaimana yang ditentukan dalam Pasal 378 KUHP.

Penjatuhan sanksi pidana terhadap Notaris dapat dilakukan selama memenuhi rumusan pelanggaran terhadap Undang-Undang Jabatan Notaris, Kode Etik Notaris, dan juga harus memenuhi rumusan atau unsur-unsur yang terdapat dalam KUHP. ${ }^{24}$ Pasal 13 UUJN menentukan bahwa "Notaris yang telah dijatuhi hukuman pidana penjara berdasarkan putusan Pengadilan yang telah memperoleh kekuatan hukum tetap karena melakukan tindak pidana yang diancam dengan pidana penjara 5 (lima) tahun atau lebih, maka Notaris yang bersangkutan dikenakan sanksi diberhentikan dengan tidak hormat dari jabatannya oleh Menteri".

\section{Bentuk Pertanggungjawaban Notaris Sebagai Penerima Titipan Sertipikat Hak Atas Tanah Milik Klien}

Notaris dalam menjalankan jabatannya sebagai seorang pejabat umum harus dapat bertanggungjawab terhadap setiap akta atau tindakan-tindakan lain yang diperbuatnya, tidak terkecuali terhadap tindakan Notaris dalam hal menjadi seorang penerima titipan sertipikat Hak Atas Tanah milik klien. Kendati dalam praktiknya tidak jarang ditemukan Notaris yang melakukan tindakan tersebut, namun Tindakan Notaris yang bersedia menerima titipan sertipikat Hak Atas Tanah milik kliennya merupakan tindakan yang melampaui kewenangannya sebagai seorang Notaris. Hal tersebut dikarenakan tidak ada peraturan perundang-undangan, baik itu dalam Undang-Undang Jabatan Notaris maupun peraturan perundang-undangan terkait lainnya yang mengatur atau memberikan kewenangan kepada Notaris untuk menerima penitipan sertipikat Hak Atas Tanah maupun barang lain milik kliennya diluar kewenangannya sebagai Notaris. Notaris sebagai pejabat umum yang memperoleh kewenangan secara atribusi atau kewenangan yang diperoleh melalui undang-undang (Undang-Undang Jabatan Notaris $)^{25}$, seharusnya dalam menjalankan jabatannya bertindak dengan mematuhi koridor undang-undang guna menghindari terjadinya suatu masalah hukum.

Selain itu jika seorang Notaris telah berkedudukan sebagai seorang penerima titipan barang, maka Notaris yang bersangkutan harus tunduk pada peraturan-peraturan yang mengatur terkait dengan penitipan barang sebagaimana yang ditentukan pada Pasal 1694 sampai dengan Pasal 1739 KUHPerdata tentang Penitipan Barang, sehingga Notaris tersebut harus menjalankan kewajiban dan tanggung jawabnya sebagai seorang penerima titipan barang. Seperti salah satunya ketentuan dalam Pasal 1706 KUHPerdata yang menentukan bahwa pihak penerima titipan wajib menjaga barang yang dititipkan kepadanya dengan sebaik-baiknya seperti menjaga barang-barang miliknya sendiri.

Jika hal tersebut terjadi, tentu Notaris yang bersangkutan akan memiliki beban tanggung jawab yang besar, karena selain harus bertanggungjawab terhadap akta yang dibuatnya, Notaris tersebut juga dalam kedudukannya sebagai seorang penerima titipan barang harus menjaga dan bertanggungjawab terhadap keutuhan sertipikat hak atas tanah milik klien sebagai barang yang dititipkan kepadanya. Jika Notaris tersebut tidak bertanggungjawab dan tidak menjaga dengan baik sertipikat hak atas tanah yang dititipkan kepadanya, sementara mengingat penitipan barang adalah termasuk suatu

\footnotetext{
${ }^{24}$ Sjaifurrachman dan Habib Adjie, Op. Cit., hlm. 209.

${ }^{25}$ Wahyuni, Kewenangan Dan Tanggung Jawab Notaris Dalam Pembuatan Akta Perjanjian Kawin Pasca Putusan Mahkamah Konstitusi No 69/PUU-XII/2015, Jurnal Ilmiah Pendidikan Pancasila dan Kewarganegaraan. Vol. 02. No. 02, 2017, http://journal2.um.ac.id/index.php/jppk/article/view/2576, diakses tanggal 2 April 2019.
} 
perjanjian, maka dengan atas dasar tindakan wanprestasi pihak yang menitipkan sertipikat hak atas tanah tersebut dapat menggungat Notaris yang bersangkutan secara perdata. Selain dapat digugat secara perdata, dalam praktiknya tidak jarang Notaris yang menerima penitipan sertipikat Hak Atas Tanah milik kliennya juga digugat secara pidana hingga dikenakan sanksi administrasi, apabila Notaris yang bersangkutan terbukti telah melakukan pelanggaran yang merugikan para pihak.

Besarnya risiko dan tanggung jawab Notaris yang berkedudukan sebagai penerima titipan barang berupa sertipikat Hak Atas Tanah milik kliennya menimbulkan potensi terjadinya pelanggaran bagi Notaris yang bersangkutan sehingga dapat berakibat timbulnya pertanggungjawaban atas tindakannya tersebut. Atas dasar itu, maka kali ini akan dibahas dan dijabarkan bentuk-bentuk pertanggungjawaban Notaris sebagai penerima titipan sertipikat Hak Atas Tanah milik kliennya, yang akan dibagi menjadi 3 bentuk pertanggungjawaban yaitu pertanggungjawaban Perdata Notaris, Pertanggungjawaban Pidana Notaris, dan Pertanggungjawaban Administratif Notaris, diantaranya sebagai berikut :

1. Pertanggungjawaban Perdata Notaris dalam Penitipan Sertipikat Hak Atas Tanah Milik Klien

1). Penggantian Biaya, Ganti Rugi dan Bunga

Pertanggungjawabanperdataberupapenggantianbiaya,gantirugidanbungaoleh Notaris terjadi apabila dalam penitipan sertipikat Hak Atas Tanah milik kliennya, Notaris yang bersangkutan mencantumkan klausul penitipan tersebut kedalam akta yang dibuatnya.

MisalnyaNotarisdalampembuatanaktaPPJB,karenaparapihakdalamaktaPPJB tersebut sepakat untuk menitipkan bukti kepemilikan objek PPJB berupa sertipikat Hak A tas Tanah kepadanya, kemudian Notaris yang bersangkutan mencantumkan klausul penitipan sertipikat tersebut kedalam akta PPJB yang dibuatnya dengan ketentuanbahwasebelumsyarat-syaratdalamPPJBterpenuhidansebelumdilakukan jual beli, maka sertipikat hak atas tanah akan dititipkan kepada Notaris, dan disertai dengan ketentuan-ketentuan lain terkait penitipan tersebut.

Sehingga atas dasar hal tersebut, maka Notaris yang bersangkutan telah menjadi pihakdariaktayangdibuatnya dan penitipantersebuttermasukperjanjianpenitipan terselubung. Notaris yang bersangkutan telah melanggar ketentuan Pasal 52 ayat (1) UUJN yang menentukanbahwa "Notaris tidak diperkenankan membuataktauntuk diri sendiri, isteri/suami, atau orang lain yang mempunyai hubungan kekeluargaan dengan Notaris baik karena perkawinan maupun hubungan darah dalam garis keturunan lurus ke bawah dan/atau ke atas tanpa pembatasan derajat, serta dalam garis ke samping sampai dengan derajat ketiga, serta menjadi pihak untuk diri sendiri, maupun dalam suatu kedudukan ataupun dengan perantara kuasa".

Adapun bentuk pertanggungjawaban Notaris terhadap hal tersebut yaitu berdasarkanPasal52 ayat(3) UUJNyang menentukanbahwa"Pelanggaranterhadap ketentuan sebagaimana dimaksud pada Pasal 52 ayat (1) berakibat akta hanya mempunyai kekuatan pembuktian sebagai akta di bawah tangan apabila akta itu ditandatanganiolehpenghadap, tanpamengurangikewajiban Notarisyangmembuat akta itu untuk membayar biaya, ganti rugi, dan bunga kepada yang bersangkutan".

Jadi dengan adanya penitipan sertipikat Hak Atas Tanah milik klien kepada Notaris, dan apabila klausul atau ketentuan terkait penitipan tersebut dicantumkan dalamaktayangdibuatolehNotarisyangbersangkutan, makaberakibataktaautentik tersebutmengalamidegradasiyaituhanyamempunyaikekuatanpembuktiansebagai 
akta di bawah tangan, sehingga pihak yang mengalami kerugian dapat melakukan tuntutan atau gugatan perdata ke Pengadilan guna mendapatkan penggantian biaya, ganti rugi, dan bunga dari Notaris yang bersangkutan.

2). Penggantian Sertipikat Hak Atas Tanah yang Hilang atau Rusak

Apabila Notaris menerima penitipan sertipikat Hak Atas Tanah milik klien kepadanya untuk disimpan, maka berdasarkan Pasal 1694 KUHPerdata telah terjadi suatu perjanjian penitipan barang, yang memberikan kedudukan Notaris sebagai pihak penerima titipan. Dengan menjadi pihak penerima titipan, maka Notaris tersebut harus tunduk pada ketentuan-ketentuan mengenai perjanjian penitipan barang sebagaimana yang ditentukan dalam Pasal 1694 sampai dengan Pasal 1739 KUHPerdata, Notaris sebagai penerima titipan harus dapat menjalankan kewajiban dan tanggung jawabnya sebagaimana yang diamanatkan oleh ketentuan dalam KUHPerdata tersebut.

Pasal 1706 KUHPerdata menentukan bahwa "si penerima titipan diwajibkan mengenai perawatan barang yang dipercayakan padanya untuk memeliharanya denganminatyangsamasepertiiamemeliharabarang-barangnyasendiri".Kemudian Pasal 1707 KUHPerdata menentukan bahwa "ketentuan Pasal 1706 KUHPerdata harus dilakukan lebih keras : 1 . Jika si penerima titipan telah menawarkan dirinya untuk menyimpan barangnya; 2. Jika ia telah meminta diperjanjikannya sesuatu upah untuk menyimpan itu; 3. Jika penitipan telah terjadi sedikit banyak untuk kepentingan si penerima titipan; 4. jika telah diperjanjikan bahwa si penerima titipan akan menanggung segala macam kelalaian".

Berdasarkan ketentuan tersebut, maka Notaris sebagai pihak penerima titipan harus menjaga dengan sebaik-baiknya sertipikat Hak Atas Tanah yang dititipkan oleh klien kepadanya. Sehingga apabila sertipikat yang dititipkan tersebut hilang atau rusak, maka Notaris tersebut memiliki tanggung jawab untuk menggantinya, sesuai dengan ketentuan Pasal 1714 KUHPerdata yang menentukan bahwa "pihak penerimatitipanbarang wajibuntukmengembalikanbarangyangsama sebagaimana yang telah diterimanya".

KendatidemikianberdasarkanPasal1708ayat(1)KUHPerdatayangmenentukan bahwa "Tidak sekali-kali si penerima titipan bertanggungjawab tentang peristiwaperistiwayangtakdapatdisingkiri,kecualiapabilaialalaidalampengembalianbarang yang dititipkan. Bahkan dalam hal yang terakhir ia juga tidak bertanggungjawab jika barangnya juga akan musnah seandainya telah berada di tangannya orang yang menitipkan", maka Notaris dapat terbebas dari tanggung jawabnya sebagai seorang penerima titipan barang selama terjadi peristiwa yang tidak dapat disangka olehnya atau dalam keadaan memaksa (overmacht atau force majeur), yaitu suatu keadaan yang tidak disengaja dan tidak dapat diduga. Namun agar dapat terbebas dari tanggung jawabnya sebagai penerima titipan, Notaris tersebut terlebih dahulu harus dapat membuktikanbahwa dirinya benar-benar sedangberada dalam keadaan memaksa dan bukan karena kelalaian, tapi apabila ia terbukti lalai, maka Notaris yang bersangkutan tetap wajib untuk bertanggungjawab atas hilang atau rusaknya sertipikat Hak Atas Tanah milik klien yang dititipkan kepadanya.

Sementara mengenai tata cara melakukan penggantian terhadap rusak atau hilangnya sertipikat Hak Atas Tanah milik klien yang dititipkan kepada Notaris, akan disampaikan berdasarkan hasil wawancara terhadap seorang Notaris yang bertempat kedudukan di Kabupaten Badung dan wilayah jabatan di Provinsi Bali, dimana Notaris tersebut pernah mengalami kehilangan sertipikat Hak Atas Tanah 
milik klien yang dititipkan kepadanya (selanjutnya disebut Notaris X). Hilangnya sertipikat Hak Atas Tanah milik klien yang dititipkan kepada Notaris X terjadi pada tahun 2014. Saat itu kantor Notaris X dibobol maling dan maling tersebut membawa kabur brankas dan merusak Closed Circuit Television (CCTV) pada kantor Notaris X. Didalam brankas tersebut terdapat kurang lebih 50 (lima puluh) sertipikat Hak Atas Tanah milik klien Notaris X yang dititipkan kepadanya untuk kepentingan akta yang dibuatnya. Berikut uraiannya tata cara penggantian SHM milik klien yang hilang tersebut: ${ }^{26}$

Pertama, Notaris X melaporkan tindak pidana pencurian tersebut ke Kantor Polisisektor KutaSelatan, yangkemudiandibuatkanberitaacara pemeriksaan(BAP) disertai dengan pernyataan kehilangan atas 50 (lima puluh) eksemplar Sertipikat Hak Milik (SHM), masing-masing lengkap dengan nomor SHM, lokasi tanah, dan atas nama SHM tersebut.

Kedua, setelah menerima BAP Kepolisian atas kehilangan tersebut, Notaris X kemudianmengajukanpemblokiransertipikatkeKantorBadanPertanahanNasional Kabupaten Badung (BPN), guna menghindari penyalahgunaan terhadap SHMyang hilang tersebut oleh pihak lain yang mencurinya, sehingga untuk sementara tanah tersebut tidak bisa dialihkan atau dijadikan jaminan. Syarat yang diajukan untuk melakukanpemblokirantersebutdiantaranyayaituBAP,fotokopiSHMdanidentitas pemilik sertipikat.

Ketiga, Notaris X melalui surat kuasa dari para pihak yang namanya tercantum sebagaipemilikSHMtersebutmenyerahkanformulirsuratpermohonanpenggantian sertipikat yang telah diisi dan ditandatangani diatas materai oleh pemilik SHM ke BPN. Formulir tersebut sebelumnya telah disediakan oleh BPN. Penyerahan formulir permohonan penggantian sertipikat tersebut juga dilengkapi dengan beberapa dokumen pendukung yang menyatakan bahwa SHM tersebut memang benar dimiliki oleh pihak yang menandatangani atau yang mengajukan formulir surat permohonan penggantian SHM, dan dokumen yang menyatakan bahwa memang benar SHM tersebut telah hilang. Adapun syarat-syarat bukti dokumen yang dilampirkan tersebutyaitu diantaranya fotokopi Kartu TandaPenduduk (KTP) pemilik SHM, fotokopi lunas Pajak Bumi dan Bangunan (PBB) terakhir, fotokopi SHM yang hilang, Kartu Keluarga pemilik SHM, surat kuasa dari pemilik SHM kepada Notaris X, dan BAP Kepolisian.

Keempat, Setelah dokumen-dokumen tersebut dinyatakan lengkap oleh pihak BPN, makakemudian pihakpemohon(pemilikSHM) membuatpernyataan dibawah sumpah yang diucapkan pemohon dihadapan rohaniawan sesuai agama pemohon dan Kepala Kantor Pertanahan atau pejabat yang ditunjuk. Sumpah tersebut berisi pernyataan pemohon akan kebenaran telah hilangnya SHM dariyangbersangkutan. Setelah mengucapkan sumpah, kemudian pemohon menandatangani pernyataan dibawah sumpahnya tersebut, dan dibuatkan Berita Acara Pengambilan Sumpah.

Kelima,PihakBPNmelakukanpemeriksaanakankelengkapanseluruhdokumen terkaitdankemudianpihakBPNmelakukanpengumumanberitaacarapengambilan sumpah pemohon mengenai kehilangan SHM tersebut di media cetak setempat, dengan tujuan untuk memastikan tidak adanya pihak lain yang merasa keberatan dengan proses penggantian SHM yang hilang itu dan memberikan waktu kepada pihak lain yang berkepentingan jika akan mengajukan gugatan atau sanggahan terhadap SHM tersebut.

\footnotetext{
${ }^{26}$ Wawancara dengan Notaris X
} 
Keenam, Pihak BPN melakukan pengukuran ulang ke lokasi tanah yang tertera pada SHM yang hilang guna memastikan tidak adanya perubahan dari surat ukur yang lama dengan kondisi fisik tanah terbaru.

Ketujuh, setelah 30 (tiga puluh) hari sejak pengumuman di media cetak oleh $\mathrm{BPN}$ dan tidak ada yang mengajukan keberatan atas penerbitan sertipikat pengganti dari SHM tersebut, maka kemudian pihak BPN menerbitkan sertipikat pengganti atas SHM yang hilang tersebut. ${ }^{27}$ Mengenai proses penerbitan sertipikat tanah pengganti tersebut diatas, telah sesuai dengan ketentuan sebagaimana yang diatur dalam Pasal 57 sampai dengan Pasal 60 Peraturan Pemerintah Nomor 24 Tahun 1997 tentang Pendaftaran Tanah. ${ }^{28}$

DalamprosespenggantianSHMtersebut,segalabiayapengurusannyaditanggung oleh Notaris X sebagai bentuk itikad baik dan pertanggungjawabannya terhadap hilangnya SHM milik klien yang dititipkan kepadanya. Setelah kejadian tersebut, Notaris X menyadari besarnya risiko menjadi penerima titipan terhadap barang milik klien, khususnya berupa sertipikat hak atas tanah. Sehingga Notaris X tidak lagi menerima penitipan sertipikat tanah atau barang apapun milik klien yang berada diluar kewenangannya sebagai Notaris.

2. Pertanggungjawaban Pidana Notaris dalam Penitipan Sertipikat Hak Atas Tanah Milik Klien

Sebagaimana yang telah dijelaskan sebelumnya, dimana pertanggungjawaban pidana atau sanksi pidana terhadap Notaris tidak diatur dalam Undang-UndangJabatan Notaris. Namun apabila seorang Notaris terindikasi melakukan pelanggaran pidana, maka Notaris yang bersangkutan tetap dapat mintai pertanggungjawabannya secara pidana, yaitu dengan merujuk pada ketentuan KUHP, dalam Pasal 63 ayat (2) KUHP yang menentukan bahwa setiap pelanggaran atau perbuatan pidana yang tidak diatur dalam aturan pidana yang khusus maka dapat dikenakan aturan pidana yang umum.

Laden Marpaung dalam bukunya menjelaskan bahwa untuk menentukan ada tidaknya suatu hubungan antara perbuatan dengan suatu pertanggungjawaban pidana maka terlebih dahulu harus dapat dijelaskan mengenai maksud dari delik pidana, sehinggakemudiandapatdisimpukanbahwaseseorangtelahmemenuhiunsurperbuatan pidana. Adapun unsur-unsur delik pidana terdiri dari $:^{29}$

1). Unsur Subjektif, yaitu yang didukung atas adanya :

a. Kesengajaan (dengan maksud, dengan keinsyafan pasti, dengan keinsyafan akan kemungkinan) dan

b. Kealpaan (tidak berhati-hati, dapat menduga, lalai);

2). Unsur objektif, yaitu yang didukung atas adanya : a. perbuatan manusia (aktif atau pasif), b. akibat perbuatan, c. sifat melawan hukum dan dapat dihukum, dan d. keadaan-keadaan.

Dalam kaitannya dengan tindakan Notaris sebagai penerima titipan sertipikat Hak Atas Tanah milik klien, mengingat besarnya risiko untuk menjadi penerima titipan barang berupa sertipikat Hak Atas Tanah, maka atas tindakan tersebut juga dapat menimbulkan pertanggungjawaban pidana berupa pengenaan sanksi pidana bagi Notaris yang melakukan penitipan tersebut. Adapun salah satu tindak pidana yang paling sering dikenakan kepada Notaris yang menjadi penerima titipan sertipikat tersebut yaitu tindak pidana penggelapan.

\footnotetext{
${ }^{27}$ Urip Santoso, Pendaftaran dan Peralihan Hak atas Tanah, Prenadamedia Group, Jakarta, 2015, hlm. 287.

${ }^{28}$ H. Arba, Hukum Agraria Indonesia, Sinar Grafika, Jakarta, 2017, hlm. 169.

${ }^{29}$ Laden Marpaung, Asas-Teori-Praktik Hukum Pidana, Sinar Grafika, Jakarta, 2008, hlm. 5.
} 
Potensi tindak pidana penggelapan pada penitipan sertipikat Hak Atas Tanah milik klienkepada Notaris dapat terjadi mengingatobjek penitipanberupa sertipikat Hak A tas Tanah adalahbarangyangmemilikinilai ekonomis tinggi, yangberadapada penguasaan Notaris (biasanya juga merupakan PPAT) yang memiliki kewenangan untuk membuat surat-surat atau akta autentik sebagai bukti telah dilakukannya perbuatan hukumberupa peralihan hak atas tanah seperti jualbeli atau sebagai salah satu bukti telah dilakukannya penjaminan barang dengan membuat surat kuasa membebankan hak tanggungan. Sehingga apabila Notaris yang menerima titipan tersebut tidak memiliki itikad baik, maka Notaris yang bersangkutan memiliki potensi yang cukup besar menyalahgunakan kewenangan jabatan yang dimilikinya untuk kemudian melakukan penggelapan yaitu dengan sengaja secara mewalan hukum memilikibarang milik oranglain (sertipikatHak Atas Tanah milik kliennya) yang berada dalam kekuasaannya bukan karena kejahatan (penitipan sertipikat Hak Atas Tanah).

Selain karena kesengajaan, Penggelapan sebagai tindak pidana yang paling sering menjerat Notaris penerima titipan barang berupa sertipikat Hak Atas Tanah milik kliennya juga dapat terjadi karena kelalaian dari Notaris yang bersangkutan. Tindak pidana penggelapan diatur dalam Pasal 372 KUHP yang menentukan bahwa "barang siapa dengan sengaja dan melawan hukum memiliki barang sesuatu yang seluruhnya atau sebagian adalah kepunyaan orang lain, tetapi yang ada dalam kekuasaannyabukankarenakejahatan diancam karenapenggelapan, dengan pidana penjara paling lama empat tahun atau pidana denda paling banyak sembilan ratus rupiah". Atas rumusan Pasal 372 KUHP tersebut, maka unsur-unsur tindak pidana penggelapan yaitu : 1). Unsur Obyektif, meliputi : mengakui sebagai milik sendiri (menguasai), sesuatu barang, yang seluruh atau sebagian milik orang lain, dan yang ada dalam kekuasaannya bukan karena kejahatan ; 2). Unsur Subyektif, meliputi : dengan sengaja, dan secara melawan hukum. ${ }^{30}$

Apabila Notaris digugat oleh para pihak atau pihak lainnya dengan tuduhan penggelapan, dan jika Notaris yang bersangkutan terbukti melakukan penggelapan terhadap sertipikat Hak Atas Tanah milik kliennya, maka berdasarkan Pasal 372 KUHP, Notaris yang bersangkutan wajib mempertanggungjawabkan perbuatannya tersebut dengan dikenakan pidana penjara paling lama 4 (empat) tahun atau pidana denda paling banyak sembilan ratus rupiah.

Selain tindak pidana penggelapan, terdapat juga risiko terjadinya pertanggungjawaban pidana berupa sanksi pidana lainnya terhadap Notaris dalam hal Notaris yang bersangkutan berkedudukan sebagai penerima titipan sertipikat Hak Atas Tanah milik kliennya, yaitu terkait tindak pidana pemalsuan surat yang disertai penyertaan, sebagaimana ditentukan dalam Pasal 263 KUHP Jo. Pasal 264 KUHP Jo. Pasal 266 KUHP Jo. Pasal 55 KUHP, dimana ancaman sanksinya paling lama yaitu pidana penjara selama 8 (delapan) tahun.

Pertanggungjawaban pemalsuan surat yang disertai penyertaan tersebut baru dapat terjadi apabila Notaris sebagai penerima titipan sertipikat Hak Atas Tanah, memiliki itikad tidak baik yang terbukti atas sepengetahuannya dengan sengaja melakukanpenggelapanataumembantumelakukanpenggelapanterhadapsertipikat Hak Atas Tanah milik klien yang dititipkan kepadanya, dengan membuatsurat-surat atau akta autentik palsu guna memuluskan tindak pidana penggelapan tersebut.

\footnotetext{
${ }^{30}$ Tongat, Hukum Pidana Materiil, UMM Press, Malang, 2006, hlm. 58.
} 
3. Pertanggungjawaban Administratif Notaris dalam Penitipan SertipikatHak Atas Tanah Milik Klien

Jika merujuk pada Undang-Undang Jabatan Notaris, maka pertanggungjawaban administratif Notaris dalam Penitipan Sertipikat Hak Atas Tanah milik kliennya baru dapat dikenakan yaitu ketika Notaris yang bersangkutan terlibat dalam kasus pidana sebagaimana yang telah dijelaskan diatas tentang pertanggungjawaban pidana Notaris dalam penitipan sertipikat hak atas tanah milik klien, dimana bentuk pertanggungjawaban administratifnya yaitu sebagai berikut :

1). Pemberhentian Sementara

Dalam Pasal 9 ayat (1) huruf e UUJN-P ditentukan bahwa "Notaris dapat diberhentikan sementara dari jabatannya salah satunya yaitu karena sedang menjalani masa penahanan". Ketentuan ini memiliki keterkaitan dengan pertanggungjawaban Notaris secara pidana, dimanajika contohnyaterdapat Notaris penerima titipan sertipikat Hak Atas Tanah milik kliennya yang ditetapkan sebagai tersangka dan ditahan karena telah melakukan tindakan pidana penggelapan yang ancaman pidananya selama empat tahun, maka Notaris yang bersangkutan dapat diberikan sanksi administratifberupa pemberhentian sementaraberdasarkan Pasal 9 ayat (1) huruf e UUJN-P tersebut.

2). Pemberhentian dengan Tidak Hormat

Pasal 13 UUJN menentukanbahwa"Notaris diberhentikandengantidakhormat oleh Menteri karena dijatuhi pidana penjara berdasarkan putusan pengadilan yang telah memperoleh kekuatan hukum tetap karena melakukan tindak pidana yang diancam dengan pidana penjara 5 (lima) tahun atau lebih". Berdasarkan ketentuan tersebut, maka Notaris yang dalam kedudukannya sebagai penerima titipan sertipikat Hak Atas Tanah milik kliennya, baru dapat dikenakan sanksi administratif berupa pemberhentian dengan tidak hormat dari jabatannya yaitu saat Notaris yang bersangkutan berdasarkan putusan Pengadilan yang mempunyai kekuatan hukum tetap, telah terbukti melakukan tindak pidana yang diancam dengan pidana penjara selama 5 (lima) tahun atau lebih.

Adapun contoh dari tindak pidana tersebut yang berpotensi dikenakan terhadap Notaris yang menjadi penerima titipan barang berupa sertipikat Hak Atas Tanah milik kliennya yaitu tindak pidana pemalsuan surat yang disertai penyertaan, sebagaimana ditentukan dalam Pasal 263 KUHP Jo. Pasal 264 KUHP Jo. Pasal 266 KUHP Jo. Pasal 55 KUHP, dimana ancaman sanksinya paling lama yaitu pidana penjara selama 8 (delapan) tahun.

\section{SIMPULAN}

Bentuk pertanggungjawaban Notaris dalam kedudukannya sebagai seorang penerima titipan sertipikat Hak Atas Tanah milik kliennya diantaranya terdiri dari : 1). Pertanggungjawaban Perdata Notaris, yaitu berupa Penggantian biaya, ganti rugi dan bunga kepada pihak yang dirugikan jika Notaris yang bersangkutan melanggar ketentuan Pasal 52 UUJN, dan Penggantian sertipikat hak atas tanah milik klien yang dititipkan apabila hilang atau rusak sesuai dengan ketentuan Pasal 1706 dan Pasal 1714 KUHPerdata;2). Pertanggungjawaban Pidana Notaris, yaitu diantaranya apabila terbukti melakukan tindak pidana penggelapan (Pasal 372 KUHP) dan terbukti melakukan tindak pidana pemalsuan surat yang disertai penyertaan (Pasal Pasal 263 KUHP Jo. Pasal 264 KUHP Jo. Pasal 266 KUHP Jo. Pasal 55 KUHP) dengan ancaman sanksi pidana penjara masing-masing paling lama empat tahun dan delapan tahun; 3). Pertanggungjawaban 
Administratif Notaris, yaitu berupa Pemberhentian sementara berdasarkan Pasal 9 ayat (1) huruf e UUJN-P apabila Notaris yang bersangkutan melakukan tindak pidana dan sedang menjalani masa penahanan, dan Pemberhentian dengan tidak hormat berdasarkan ketentuan Pasal 13 UUJN apabila Notaris yang bersangkutan dihukum berdasarkan putusan pengadilan yang telah memperoleh kekuatan hukum tetap yang diancam dengan pidana penjara 5 tahun atau lebih.

\section{DAFTAR PUSTAKA}

\section{Buku}

E. Sumaryono, (1995), Etika Profesi Hukum : Norma-Norma Bagi Penegak Hukum, Kanisius, Yogyakarta.

Edi Yunara, (2012), Korupsi dan Pertanggungjawaban Pidana Korporasi, Citra Aditya Bakti, Bandung.

H. Arba, (2017), Hukum Agraria Indonesia, Sinar Grafika, Jakarta.

Habib Adjie, (2009), Sanksi Perdata dan Administratif Terhadap Notaris Sebagai Pejabat Publik, Refika Aditama, Bandung.

(2015), Penafsiran Tematik Hukum Notaris Indonesia : Berdasarkan UndangUndang Nomor 2 Tahun 2014 tentang Perubahan Atas Undang-Undang Nomor 30 Tahun 2004 tentang Jabatan Notaris, PT. Refika Aditama, Bandung.

Herlien Budiono, (2018), Demikian Akta Ini : Tanya Jawab Mengenai Pembuatan Akta Notaris di dalam Praktik, PT. Citra Aditya Bakti, Bandung.

Laden Marpaung, (2008), Asas-Teori-Praktik Hukum Pidana, Sinar Grafika, Jakarta.

Liliana Tedjosaputro, (1991), Mal Praktek Notaris Dalam Hukum Pidana, CV. Agung, Semarang.

M. Luthfan Hadi Darus, (2017), Hukum Notariat dan Tanggung Jawab Jabatan Notaris, UII Press, Yogyakarta.

Munir Fuady, (2010), Perbuatan Melawan Hukum, PT Citra Aditya Bakti, Bandung.

Purnadi Purbacaraka, (2010), Perihal Kaedah Hukum, Citra Aditya, Bandung.

Ridwan H.R., (2006), Hukum Adminstrasi Negara, Raja Grafindo Persada, Jakarta.

Salim H.S., (2018), Peraturan Jabatan Notaris, Sinar Grafika, Jakarta.

Sjaifurrachman dan Habib Adjie, (2011), Aspek Pertanggungjawaban Notaris dalam Pembuatan Akta, CV. Mandar Maju, Bandung.

Sulhan, Irwansyah Lubis, dan Anhar Syahnel, (2018), Buku 1 : Profesi Notaris dan Pejabat Pembuat Akta Tanah (Pandua Praktis Dan Murah Taat Hukum), Mitra Wacana Media, Bogor.

Tim Penyusun Kamus Pusat Pembinaan dan Pengembangan Bahasa. (1989), Kamus Besar Bahasa Indonesia, Balai Pustaka, Jakarta.

Titik Triwulan dan Shinta Febrian, (2010), Perlindungan Hukum Bagi Pasien, Prestasi Pustaka, Jakarta.

Tongat, (2006), Hukum Pidana Materiil, UMM Press, Malang.

Urip Santoso, (2015), Pendaftaran dan Peralihan Hak atas Tanah, Prenadamedia Group, 
Jakarta.

\section{Journal}

Puspo Dewi Retno, Pranoto dan Purwadi Hari, "Pembatalan Akta Perjanjian Pengikatan Jual Beli Akibat Wanprestasi (Studi Kasus Putusan Nomor: 200/Pdt.G/2012/PN.Jkt. Sel)", Jurnal Repertorium 4.7 (2017), https://jurnal.uns.ac.id/repertorium/article/ download/18296/14498, diakses tanggal 2 April 2019.

Putri, Dewi Kunia dan Purnawan, Amin, "Perbedaan Perjanjian Pengikatan Jual Beli Lunas dengan Perjanjian Pengikatan Jual Beli Tidak Lunas”, Jurnal Akta 4.4 (2017), http:// jurnal.unissula.ac.id/index.php/akta/article/download/2505/1868, diakses tanggal 2 April 2019.

Supriyadi, "Kedudukan Perjanjian Pengikatan Jual Beli Hak Atas Tanah Dalam Perspektif Hukum Pertanahan", Arena Hukum 10.2 (2017), https://doi.org/10.21776/ ub.arenahukum.2017.01002.3, diakses tanggal 2 April 2019.

Wahyuni, "Kewenangan Dan Tanggung Jawab Notaris Dalam Pembuatan Akta Perjanjian Kawin Pasca Putusan Mahkamah Konstitusi No 69/PUU-XII/2015”, Jurnal Ilmiah Pendidikan Pancasila dan Kewarganegaraan 2.2 (2017), http://journal2.um.ac.id/ index.php/jppk/article/view/2576, diakses tanggal 2 April 2019.

\section{Peraturan Perundang-Undangan}

Indonesia, Kitab Undang-undang Hukum Perdata, sebagaimana dimuat berdasarkan Staatsblaad Nomor 23 Tahun 1847, Burgelijk Wetboek, 2009, diterjemahkan oleh R. Soebekti dan R. Tjirosudibio, PT. Pradnya Paramita, Jakarta.

Indonesia, Undang-Undang tentang Peraturan Dasar Pokok-Pokok Agraria, UndangUndang Republik Indonesia Nomor 5 Tahun 1960, Lembaran Negara Republik Indonesia Nomor 104 Tahun 1960, Tambahan Lembaran Negara Republik Indonesia Nomor 2043.

Indonesia, Undang-Undang tentang Jabatan Notaris, Undang-Undang Republik Indonesia Nomor 30 Tahun 2004, Lembaran Negara Republik Indonesia Nomor 117 Tahun 2004, Tambahan Lembaran Negara Republik Indonesia Nomor 4432.

Indonesia, Undang-Undang tentang Jabatan Notaris, Undang-Undang Republik Indonesia Nomor 2 Tahun 2014 tentang Perubahan Atas Undang-undang Nomor 30 Tahun 2004, Lembaran Negara Republik Indonesia Nomor 3, Tahun 2014, Tambahan Lembaran Negara Republik Indonesia Nomor 5491.

Indonesia, Peraturan Pemerintah tentang Pendaftaran Tanah, Peraturan Pemerintah Republik Indonesia Nomor 24 Tahun 1997, Lembaran Negara Republik Indonesia Nomor 59 Tahun 1997, Tambahan Lembaran Negara Republik Indonesia Nomor 3696. 